Article

\title{
In Vitro and In Vivo Trypanocidal Efficacy of Synthesized Nitrofurantoin Analogs
}

\author{
Linous Munsimbwe ${ }^{1}$, Anna Seetsi ${ }^{2}$ (D), Boniface Namangala ${ }^{3}$, David D. N'Da ${ }^{4}$, Noboru Inoue ${ }^{5}$ \\ and Keisuke Suganuma ${ }^{6, *}$
}

1 Ministry of Fisheries and Livestock, Department of Veterinary Services, Mulungushi House, P.O. Box 50600, Ridgeway, Lusaka 15100, Zambia; munsimbwe@yahoo.com

2 Unit for Environmental Science and Management, Faculty of Natural and Agricultural Sciences, North-West University, Potchefstroom 2531, South Africa; annaseetsi@gmail.com

3 Department of Paraclinical Studies, School of Veterinary Medicine, University of Zambia, P.O. Box 32379, Lusaka 10101, Zambia; b.namangala@unza.zm

4 Centre of Excellence for Pharmaceutical Sciences (PHARMACEN), North-West University, Potchefstroom 2520, South Africa; david.nda@nwu.ac.za

5 OIE Reference Laboratory for Surra, National Research Centre for Protozoan Diseases, Obihiro University of Agriculture and Veterinary Medicine, Obihiro, Hokkaido 080-8555, Japan; ircpmi@obihiro.ac.jp

6 Research Center for Global Agromedicine, Obihiro University of Agriculture and Veterinary Medicine, Obihiro, Hokkaido 080-8555, Japan

* Correspondence: k.suganuma@obihiro.ac.jp; Tel.: +81-155-49-5697

Citation: Munsimbwe, L.; Seetsi, A.; Namangala, B.; N’Da, D.D.; Inoue, N.; Suganuma, K. In Vitro and In Vivo Trypanocidal Efficacy of Synthesized Nitrofurantoin Analogs. Molecules 2021, 26, 3372. https://doi.org/ $10.3390 /$ molecules 26113372

Academic Editors: Paula A. C. Gomes and Diego Muñoz-Torrero

Received: 26 April 2021

Accepted: 25 May 2021

Published: 2 June 2021

Publisher's Note: MDPI stays neutral with regard to jurisdictional claims in published maps and institutional affiliations.

Copyright: (c) 2021 by the authors. Licensee MDPI, Basel, Switzerland. This article is an open access article distributed under the terms and conditions of the Creative Commons Attribution (CC BY) license (https:// creativecommons.org/licenses/by/ $4.0 /)$.
Abstract: African trypanosomes cause diseases in humans and livestock. Human African trypanosomiasis is caused by Trypanosoma brucei rhodesiense and T. b. gambiense. Animal trypanosomoses have major effects on livestock production and the economy in developing countries, with disease management depending mainly on chemotherapy. Moreover, only few drugs are available and these have adverse effects on patients, are costly, show poor accessibility, and parasites develop drug resistance to them. Therefore, novel trypanocidal drugs are urgently needed. Here, the effects of synthesized nitrofurantoin analogs were evaluated against six species/strains of animal and human trypanosomes, and the treatment efficacy of the selected compounds was assessed in vivo. Analogs 11 and 12, containing 11- and 12-carbon aliphatic chains, respectively, showed the highest trypanocidal activity $\left(\mathrm{IC}_{50}<0.34 \mu \mathrm{M}\right)$ and the lowest cytotoxicity $\left(\mathrm{IC}_{50}>246.02 \mu \mathrm{M}\right)$ in vitro. Structure-activity relationship analysis suggested that the trypanocidal activity and cytotoxicity were related to the number of carbons in the aliphatic chain and electronegativity. In vivo experiments, involving oral treatment with nitrofurantoin, showed partial efficacy, whereas the selected analogs showed no treatment efficacy. These results indicate that nitrofurantoin analogs with high hydrophilicity are required for in vivo assessment to determine if they are promising leads for developing trypanocidal drugs.

Keywords: animal trypanosomosis; human African trypanosomiasis; nitrofurantoin analog; trypanocidal drug

\section{Introduction}

African trypanosomes, transmitted by tsetse fly, cause several diseases in both humans and livestock on the Sub-Saharan African continent. Human African trypanosomiasis (HAT) is caused by Trypanosoma brucei gambiense and T. $b$. rhodesiense. The disease has devastating socio-economic impacts, such as reduced income generation, negative effects on the education of children, increased healthcare costs, and long-term health consequences [1, 2]. In contrast, animal African trypanosomosis, which is caused by T. congolense, T. vivax, and T. brucei brucei, represents a major health concern in animal development, and its deleterious impacts can be manifested in terms of reduced livestock productivity, costly disease control, and trade implications, as well as negative impacts on agriculture and 
food security [3,4]. Surra is an animal trypanosomosis caused by T. evansi infection. It is mechanically transmitted by hematophagous biting flies such as Tabanus spp., Stomoxys spp., and species of tsetse flies [5]. Animal trypanosomoses (AT), including animal African trypanosomosis and surra, are economically important diseases in animals. They cause high mortality, low milk and meat production, poor carcass quality, reduced reproductive performance, and decreased draught animal power and manure production, as well as immunosuppression in livestock $[3,5]$.

HAT / AT control requires an integrated approach involving the use of trypanocidal drugs [3,6], reduction in the number of vectors, and low contact between hosts and vectors [7]. Owing to the challenges in vector control programs and vaccine development, HAT / AT control primarily depends on chemotherapy using anti-parasitic agents. Currently, the nifurtimox-eflornithine combination therapy (NECT) and fexinidazole are approved for treating HAT caused by T. b. gambiense [8]. Particularly, fexinidazole was the first oral drug approved for HAT treatment, which shows satisfactory treatment efficacy against second-stage HAT, as compared to the nifurtimox-eflornithine combination therapy [9]. In contrast, no orally administered and safe drugs are available against HAT caused by T. $b$. rhodesiense and AT. Therefore, the screening and development of safe and effective compounds for treating HAT/AT are urgently required.

Nitrofurantoin is a hypoxic agent with activity against a myriad of anaerobic pathogens. This nitrofuran compound contains a Schiff base derived from 5-nitrofuraldehyde, which is known to be effective against a wide spectrum of gram-positive and gram-negative bacteria and various pathogens, including trypanosomes [10,11]. Nitrofurantoin analogs show good safety profiles, enhanced anti-mycobacterial potency, improved lipophilicity, and a reduced protein-binding affinity. Nitrofurans are broad-spectrum redox-active antibiotics, with dose-dependent bacteriostatic or bactericidal activity [10,12], and have been used in animal feeds, pharmaceuticals, and other applications [11,13].

The clinical drug furazolidone belongs to the group of nitrofuran antibiotics and has been widely used as an antibacterial and antiprotozoal feed additive for poultry, cattle, and farmed fish [11,14]. Nifurtimox, another nitrofuran derivative, which was developed in the 1960s, has been used to treat Chagas disease caused by T. cruzi. More recently, the combination of nifurtimox and eflornithine was evaluated for the treatment of late-stage T. $b$. gambiense sleeping sickness [15-17]. Furthermore, a study revealed that chemically synthesized analogs of nitrofurantoin had significantly enhanced antimycobacterial activity [11]. Overall, these reports suggest that some nitrofurantoin analogs can be used against African trypanosomes. Therefore, the aim of the study was to evaluate the in vitro trypanocidal activity of these chemically synthesized nitrofurantoin analogs (Table 1) and in vivo treatment efficacy of three promising analogs against human and animal trypanosomes.

Table 1. Structures of synthesized nitrofurantoin analogues 1-19.

\begin{tabular}{|c|c|c|c|}
\hline Cpd. & MW (g/mol) & Name & Structure \\
\hline 1 & 252.18 & $\begin{array}{l}\text { (E)-3-Methyl-1-([(5-nitrofuran-2-yl) } \\
\text { methylene]amino)imidazolidine-2,4-dione }\end{array}$ & \\
\hline 2 & 266.21 & $\begin{array}{l}(E)-3 \text {-Ethyl-1-([(5-nitrofuran-2-yl) } \\
\text { methylene]amino)imidazolidine-2,4-dione }\end{array}$ & \\
\hline 3 & 280.24 & $\begin{array}{l}(E)-1-([(5-N i t r o f u r a n-2-y l) \\
\text { methylene]amino)-3-propylimidazolidine-2,4-dione }\end{array}$ & \\
\hline
\end{tabular}


Table 1. Cont.

\begin{tabular}{|c|c|c|c|}
\hline Cpd. & MW (g/mol) & Name & Structure \\
\hline 4 & 294.26 & $\begin{array}{l}(E)-3-B u t y l-1-([(5-n i t r o f u r a n-2-y l) \\
\text { methylene]amino)imidazolidine-2,4-dione }\end{array}$ & \\
\hline 5 & 30,829 & $\begin{array}{l}\text { (E)-1-([(5-Nitrofuran-2-yl)methylene }] \\
\text { amino)-3-pentylimidazolidine-2,4-dione }\end{array}$ & \\
\hline 6 & 322.32 & $\begin{array}{l}\text { (E)-3-Hexyl-1-([(5-nitrofuran-2-yl) } \\
\text { methylene]amino)imidazolidine-2,4-dione }\end{array}$ & \\
\hline 7 & 336.34 & $\begin{array}{l}\text { (E)-3-Heptyl-1-([(5-nitrofuran-2-yl) } \\
\text { methylene]amino)imidazolidine-2,4-dione }\end{array}$ & \\
\hline 8 & 350.37 & $\begin{array}{l}\text { (E)-1-([(5-Nitrofuran-2-yl)methylene }] \\
\text { amino)-3-octylimidazolidine-2,4-dione }\end{array}$ & \\
\hline 9 & 364.4 & $\begin{array}{l}\text { (E)-1-([(5-Nitrofuran-2-yl)methylene }] \\
\text { amino)-3-nonylimidazolidine-2,4-dione }\end{array}$ & \\
\hline 10 & 378.42 & $\begin{array}{l}\text { (E)-3-Decyl-1-([(5-nitrofuran-2-yl)methylene }] \\
\text { amino)imidazolidine-2,4-dione }\end{array}$ & \\
\hline 11 & 392.45 & $\begin{array}{l}\text { (E)-1-([(5-Nitrofuran-2-yl)methylene] } \\
\text { amino)-3-undecylimidazolidine-2,4-dione }\end{array}$ & \\
\hline 12 & 406.48 & $\begin{array}{l}\text { (E)-3-Dodecyl-1-([(5-nitrofuran-2-yl) } \\
\text { methylene]amino)imidazolidine-2,4-dione }\end{array}$ & \\
\hline 13 & 356.33 & $\begin{array}{l}\text { (E)-1-([(5-Nitrofuran-2-yl)methylene] } \\
\text { amino)-3-(3-phenylpropyl)imidazolidine-2,4-dione }\end{array}$ & \\
\hline 14 & 328.28 & $\begin{array}{l}\text { (E)-3-Benzyl-1-([(5-nitrofuran-2-yl) } \\
\text { methylene]amino)imidazolidine-2,4-dione }\end{array}$ & \\
\hline 15 & 342.31 & $\begin{array}{l}\text { (E)-3-(p-Methylbenzyl)-1-([(5-nitrofuran-2-yl) } \\
\text { methylene]amino)imidazolidine-2,4-dione }\end{array}$ & \\
\hline 16 & 396.28 & $\begin{array}{c}(E)-1-([(5-N i t r o f u r a n-2-y l) m e t h y l e n e] \\
\text { amino)-3-(p-(trifluoromethyl)benzyl) } \\
\text { imidazolidine-2,4-dione }\end{array}$ & \\
\hline 17 & 373.28 & $\begin{array}{l}(E)-3-(p-N i t r o b e n z y l)-1-([(5-n i t r o f u r a n-2-y l) \\
\text { methylene }] \text { amino }) \text { imidazolidine-2,4-dione }\end{array}$ & \\
\hline 18 & 358.31 & $\begin{array}{l}\text { (E)-3-(p-Methoxybenzyl)-1-([(5-nitrofuran-2-yl) } \\
\text { methylene]amino)imidazolidine-2,4-dione }\end{array}$ & \\
\hline 19 & 407.18 & $\begin{array}{l}\text { (E)-3-(p-Bromobenzyl)-1-([(5-nitrofuran-2-yl) } \\
\text { methylene]amino)imidazolidine-2,4-dione }\end{array}$ & \\
\hline
\end{tabular}




\section{Results}

\subsection{In Vitro Experiment}

A summary of the trypanocidal activity and cytotoxicity data of the nitrofurantoin analogs is shown in Table 2.

Trypanocidal activities differed among the trypanosome species. However, T. congolense IL3000 and T. b. rhodesiense Chirundu were more sensitive to these nitrofurantoin analogs than the other trypanosome strains/species.

The strongest trypanocidal activity $\left(\mathrm{IC}_{50}<0.031 \mu \mathrm{M}\right)$ against $T$. congolense IL3000 and T. b. rhodesiense Chirundu was observed with the long chain analogs $\mathbf{9 - 1 2}$, bearing side chains of 9-11 carbons, respectively $(n=9-12)$, in sub-series 1 . These analogs showed relatively moderate $(0.16-0.65 \mu \mathrm{M})$ activity against T. evansi Tansui, T. b. brucei GUTat3.1, T. b. gambiense IL1922, and T. b. rhodesiense IL1501.

Furthermore, variation in the trypanocidal activity for analogs in sub-series 2 was found based on the electronegativity of para-substituents on the phenyl ring. The trypanocidal activity of analogs bearing electron-withdrawing groups $(16,17$, and 19) was stronger than that of analog 14, featuring a neutral group and those of analogs 15 and 18 possessing electron-donating groups. In contrast, electronegativity had no effect on cytotoxicity within sub-series 2.

\subsection{In Vivo Experiment}

The in vivo trypanocidal activity of three selected nitrofurantoin analogs $(\mathbf{9}, \mathbf{1 1}$, and 12) showed strong trypanocidal activity and were used to confirm the results of in vitro assay and nitrofurantoin. These three analogs were evaluated. All mice treated with nitrofurantoin and its analogs by intraperitoneal injection at $0.1 \mathrm{mg} / \mathrm{kg}$, died within $9 \mathrm{dpi}$, because of high parasitemia (Figure 1a). All mice orally treated with the three analogs at $10 \mathrm{mg} / \mathrm{kg}$ also succumbed to high parasite levels within $9 \mathrm{dpi}$. In contrast, two of three mice orally treated at $10 \mathrm{mg} / \mathrm{kg}$ with nitrofurantoin, survived until end of the experiment period (Figure 1b). 
Table 2. In vitro biological activities of synthesized nitrofurantoin analogs.

\begin{tabular}{|c|c|c|c|c|c|c|c|c|c|c|c|c|c|c|c|}
\hline \multirow[b]{2}{*}{ ID } & \multirow[b]{2}{*}{$\mathbf{N}^{a}$} & \multirow[b]{2}{*}{$\underset{b}{\operatorname{cog} P}$} & \multirow[b]{2}{*}{$\begin{array}{c}\text { Tbb } \\
\text { GUTat3.1 }\end{array}$} & \multirow[b]{2}{*}{ Tbg IL1922 } & \multicolumn{2}{|c|}{$\begin{array}{l}\text { Trypanocidal Activity } \\
\mathrm{IC}_{50} \pm \mathrm{SD}(\mu \mathrm{M})^{\mathrm{c}}\end{array}$} & \multirow[b]{2}{*}{ Tc IL3000 } & \multirow[b]{2}{*}{ Tev Tansui } & \multirow{2}{*}{$\begin{array}{c}\begin{array}{c}\text { Cytotoxicity } \\
\text { IC } \\
(\mu 0 \pm \mathrm{SD})^{\mathrm{c}}\end{array} \\
\text { MDBK }\end{array}$} & \multicolumn{6}{|c|}{ 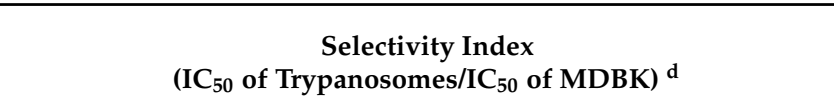 } \\
\hline & & & & & Tbr IL1501 & $\begin{array}{c}\text { Tbr } \\
\text { Chirundu }\end{array}$ & & & & $\begin{array}{c}\text { Tbb } \\
\text { GUTat3.1 }\end{array}$ & $\begin{array}{c}\text { Tbg } \\
\text { IL1922 }\end{array}$ & $\begin{array}{c}\text { Tbr } \\
\text { IL1501 }\end{array}$ & $\begin{array}{c}\text { Tbr } \\
\text { Chirundu }\end{array}$ & $\begin{array}{c}\text { Tc } \\
\text { IL3000 }\end{array}$ & $\begin{array}{c}\text { Tev } \\
\text { Tansui }\end{array}$ \\
\hline 1 & 1 & -0.04 & $3.61 \pm 0.40$ & $3.60 \pm 0.26$ & $7.02 \pm 0.094$ & $0.73 \pm 0.17$ & $0.19 \pm 0.076$ & $1.61 \pm 0.098$ & $65.21 \pm 12.78$ & 18 & 18 & 9 & 89 & 342 & 41 \\
\hline 2 & 2 & 0.36 & $10.81 \pm 4.84$ & $11.31 \pm 4.80$ & $11.40 \pm 5.24$ & $0.51 \pm 0.25$ & $0.42 \pm 0.16$ & $5.39 \pm 0.53$ & $44.79 \pm 1.69$ & 4 & 4 & 4 & 87 & 108 & 8 \\
\hline 3 & 3 & 0.88 & $14.13 \pm 0.34$ & $14.73 \pm 1.32$ & $14.02 \pm 1.42$ & $0.81 \pm 0.24$ & $0.33 \pm 0.18$ & $6.53 \pm 0.61$ & $39.29 \pm 1.09$ & 3 & 3 & 3 & 49 & 120 & 6 \\
\hline 4 & 4 & 1.33 & $33.29 \pm 24.29$ & $17.25 \pm 2.23$ & $32.74 \pm 0.82$ & $1.38 \pm 0.34$ & $0.31 \pm 0.20$ & $7.89 \pm 0.53$ & $35.78 \pm 3.49$ & 1 & 2 & 1 & 26 & 117 & 5 \\
\hline 5 & 5 & 1.77 & $4.24 \pm 1.99$ & $3.42 \pm 1.47$ & $5.69 \pm 1.66$ & NA & $0.35 \pm 0.15$ & $5.44 \pm 0.17$ & $39.07 \pm 5.86$ & 9 & 11 & 7 & NA & 112 & 7 \\
\hline 7 & 7 & 2.66 & $2.06 \pm 0.75$ & $1.99 \pm 0.75$ & $1.45 \pm 0.86$ & $0.056 \pm 0.026$ & $0.040 \pm 0.011$ & $1.02 \pm 0.10$ & $92.28 \pm 6.52$ & 45 & 46 & 64 & 1654 & 2323 & 90 \\
\hline 8 & 8 & 3.10 & $1.89 \pm 0.69$ & $1.40 \pm 0.73$ & $1.38 \pm 0.82$ & $\begin{array}{c}0.039 \pm \\
0.0084\end{array}$ & $\begin{array}{c}0.030 \pm \\
0.0050\end{array}$ & $0.81 \pm 0.082$ & $84.74 \pm 8.99$ & 45 & 61 & 62 & 2195 & 2809 & 105 \\
\hline 9 & 9 & 3.55 & $0.57 \pm 0.22$ & $0.44 \pm 0.17$ & $0.60 \pm 0.54$ & $\begin{array}{r}0.017 \pm \\
0.0067\end{array}$ & $\begin{array}{c}0.010 \pm \\
0.0035\end{array}$ & $0.27 \pm 0.025$ & $251.18 \pm 58.27$ & 443 & 567 & 420 & 14,645 & 25,639 & 918 \\
\hline 10 & 10 & 3.99 & $0.65 \pm 0.56$ & $0.62 \pm 0.70$ & $0.61 \pm 0.06$ & $\begin{array}{c}0.017 \pm \\
0.0044\end{array}$ & $\begin{array}{c}0.011 \pm \\
0.0044\end{array}$ & $0.28 \pm 0.025$ & $110.45 \pm 14.38$ & 170 & 177 & 180 & 6645 & 10,502 & 402 \\
\hline 11 & 11 & 4.44 & $0.33 \pm 0.12$ & $0.33 \pm 0.12$ & $0.24 \pm 0.13$ & $\begin{array}{c}0.021 \pm \\
0.0094\end{array}$ & $\begin{array}{c}0.011 \pm \\
0.0035\end{array}$ & $0.16 \pm 0.014$ & $>254.81$ & 764 & 771 & 1052 & 11,933 & 21,978 & 1602 \\
\hline 12 & 12 & 4.88 & $0.34 \pm 0.12$ & $0.23 \pm 0.13$ & $0.26 \pm 0.11$ & $0.031 \pm 0.011$ & $\begin{array}{c}0.012 \pm \\
0.0045\end{array}$ & $0.20 \pm 0.017$ & $>246.02$ & 715 & 1095 & 934 & 7937 & 21,322 & 1253 \\
\hline 14 & & 1.73 & $2.88 \pm 0.26$ & $2.34 \pm 0.64$ & $2.83 \pm 0.61$ & $0.27 \pm 0.12$ & $0.18 \pm 0.017$ & $1.26 \pm 0.10$ & $>304.62$ & 106 & 130 & 108 & 1142 & 1702 & 241 \\
\hline 15 & & 2.24 & $8.24 \pm 3.11$ & $2.89 \pm 0.51$ & $6.10 \pm 0.047$ & $0.15 \pm 0.068$ & $0.13 \pm 0.044$ & $4.23 \pm 0.40$ & $34.28 \pm 11.5$ & 4 & 12 & 6 & 231 & 271 & 8 \\
\hline 16 & & 2.60 & $0.52 \pm 0.081$ & $0.61 \pm 0.26$ & $0.96 \pm 0.0087$ & $0.02 \pm 0.012$ & $0.02 \pm 0.073$ & $0.44 \pm 0.046$ & $56.62 \pm 40.76$ & 108 & 93 & 59 & 3121 & 3802 & 128 \\
\hline 17 & & 1.67 & $1.07 \pm 0.74$ & $1.05 \pm 0.70$ & $0.50 \pm 0.012$ & $0.04 \pm 0.094$ & $0.04 \pm 0.017$ & $0.61 \pm 0.050$ & $20.10 \pm 1.02$ & 19 & 19 & 45 & 497 & 469 & 33 \\
\hline 18 & & 1.57 & $9.91 \pm 0.092$ & $9.78 \pm 0.31$ & $10.14 \pm 0.62$ & $0.33 \pm 0.22$ & $0.14 \pm 0.030$ & $2.40 \pm 0.19$ & $80.09 \pm 36.89$ & 8 & 8 & 8 & 244 & 585 & 33 \\
\hline 19 & & 2.50 & $2.13 \pm 0.23$ & $2.04 \pm 0.091$ & $2.47 \pm 0.69$ & $0.041 \pm 0.025$ & $0.049 \pm 0.033$ & $1.15 \pm 0.11$ & $28.74 \pm 5.69$ & 14 & 14 & 12 & 700 & 587 & 25 \\
\hline \multirow{3}{*}{\multicolumn{2}{|c|}{$\begin{array}{l}\text { Nitrofurantoin } \\
\text { Nifurtimox } \\
\text { Eflornithine }\end{array}$}} & -0.22 & $1.42 \pm 0.15$ & $1.62 \pm 0.28$ & $1.42 \pm 0.25$ & NA & $0.36 \pm 0.043$ & $1.96 \pm 0.50$ & & & & & & & \\
\hline & & & $4.66 \pm 19.7$ & $4.58 \pm 2.38$ & $4.35 \pm 1.59$ & $1.46 \pm 0.35$ & $1.06 \pm 0.22$ & $2.62 \pm 1.40$ & & & & & & & \\
\hline & & & $38.56 \pm 9.88$ & $36.66 \pm 12.87$ & $45.99 \pm 17.07$ & $35.65 \pm 10.16$ & $16.13 \pm 2.93$ & $57.21 \pm 17.56$ & & & & & & & \\
\hline \multicolumn{2}{|c|}{ Pentamidine } & & $\begin{array}{c}0.041 \pm \\
0.0023\end{array}$ & $\begin{array}{c}0.014 \pm \\
0.0031\end{array}$ & $\begin{array}{c}0.029 \pm \\
0.0062\end{array}$ & $0.050 \pm 0.012$ & $0.33 \pm 0.054$ & $\begin{array}{c}0.00097 \pm \\
0.00019\end{array}$ & & & & & & & \\
\hline \multicolumn{2}{|c|}{ Suramin } & & $\begin{array}{c}0.066 \pm \\
0.0052\end{array}$ & $\begin{array}{c}0.064 \pm \\
0.0018\end{array}$ & $0.076 \pm 0.011$ & $0.066 \pm 0.071$ & $7.17 \pm 0.87$ & $0.38 \pm 0.058$ & & & & & & & \\
\hline
\end{tabular}

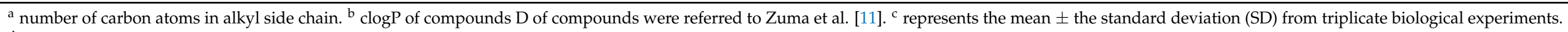

$\mathrm{d}$ value as rounded off to the nearest digit. NA—not analyzed. 


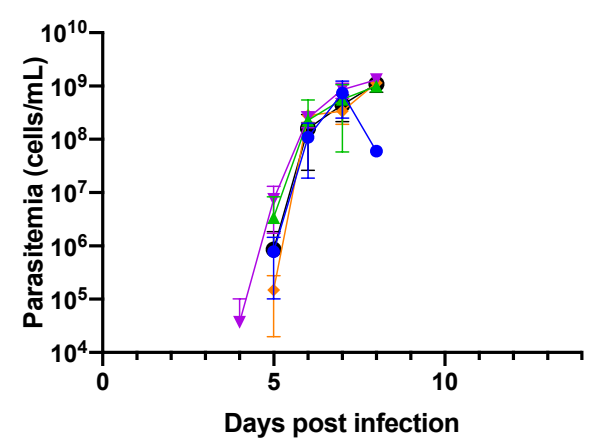

(a)

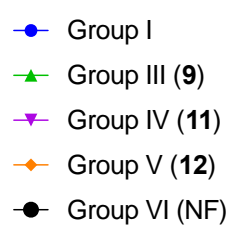

- Group VI (NF)

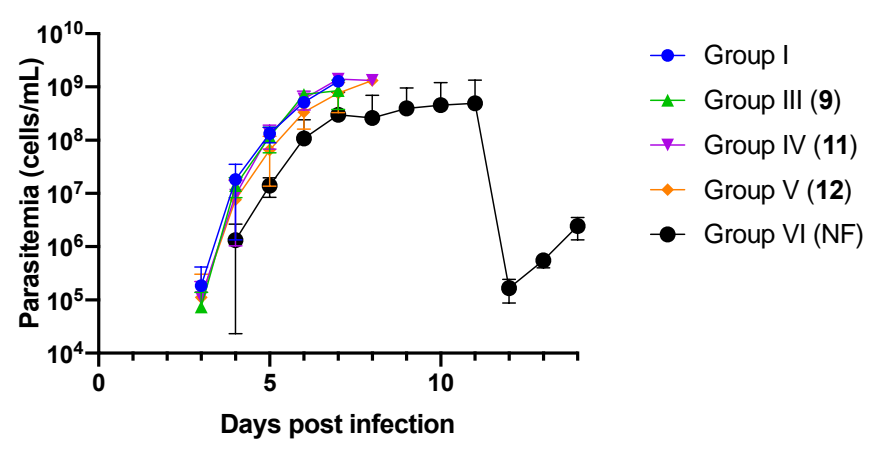

(b)

Figure 1. In vivo analysis of selected nitrofurantoin analogs and nitrofurantoin (NF). Evaluation of parasitemia in mice infected with T. congolense and intraperitoneal or orally treated with nitrofurantoin analogs (9, 11, and 12) and nitrofurantoin. The $\mathrm{Y}$ axis shows $\log 10$ scale, and the data are shown as mean \pm standard deviation. Parasitemia was not observed in group II (diminazene aceturate treatment). (a) Treatment of mice by intraperitoneal injection at $0.1 \mathrm{mg} / \mathrm{kg}$. (b) Treatment of mice by oral administration at $10 \mathrm{mg} / \mathrm{kg}$.

\section{Discussion}

In the present study, the trypanocidal activity of 19 nitrofurantoin analogs was evaluated against six human and animal trypanosomes in vitro. Investigation of the structureactivity relationship within the series revealed that the trypanocidal activity of short alkyl analogs (1-4) in sub-series 1 decreased with increasing chain lengths up to four carbons $(n=$ 4, 4) (Figure 2a). The trypanocidal activity in long alkyl chain analogs (5-12) increased with increasing chain lengths up to 12 carbons $(n=12,12)$ (Figure 2a). The cytotoxicity within the analogs of sub-series 1 mostly increased with increasing chain lengths (Figure 2a). The strongest trypanocidal activity of these long alkyl chains (9-11) in sub-series 1 may be related to their higher lipophilicity, which increased the cLogP value. This feature is typically associated with better permeation of a molecule through biological tissues/membranes, as well as interactions with transporter proteins and enzymes [18]. Similar results were previously observed against the T. cruzi parasite $[19,20]$. Various studies have indicated a relationship between trypanocidal activity and the number of carbon atoms in the alkyl chain of the compounds [21,22].

Additionally, we showed that the trypanocidal activity of analogs bearing electronwithdrawing groups $(16,17$, and 19) was stronger than that of the compounds containing a neutral group (14) and those bearing electron-donating groups (15 and 18) in sub-series 2 (Figure 2b). Electronegativity was also reported to affect the trypanocidal activity [23-25]. Our results are similar to the previous findings, except for the differences in the values. The trypanocidal activity of the nitrofurantoin analogs increased with increasing chain length, up to a certain number of carbon atoms and electronegativity. Our results confirm previous findings and extend the range of promising compounds that are optimized by a combination of chemical modifications with long alkyl chain and high electronegativity. This can be strategized using a fragment-based, drug-discovery approach to enhance the trypanocidal activity of nitrofurantoin. The presence of an electronegative electronwithdrawing group in the ortho- or meta-position on the phenyl ring may also influence activity. However, these structure-activity relationships must be confirmed in further experiments by investigating derivatives bearing such substituents.

Furthermore, the selectivity index, which indicates the selectivity of the antipathogenic action of a compound in the presence of normal/healthy mammalian cells (Table 2), showed that most analogs had a selectivity index $>10$, which is a minimum criterion value for selecting a synthetic drug hit [26]. Therefore, most analogs were hits, with activity $\mathrm{IC}_{50}$ $<10 \mu \mathrm{M}$ and selectivity index $>10$ [26]. Despite being mild to weakly toxic towards Madin- 
Darby bovine kidney cells $[27,28]$, these analogs were up to $10-100$-fold selective in their trypanocidal action.

Hall et al. suggested that trypanosomal type I nitroreductase reduces nitrofuran compounds, and that the toxic intermediate metabolites kill the parasites [29]. They also revealed that an increased expression level of this enzyme makes T. b. brucei more sensitive to nifurtimox and its related compounds [12]. The current study revealed differences in the sensitivities of the evaluated trypanosome species and strains to the 19 nitrofurantoin analogs. This may explain the difference in the expression level of trypanosomal type I nitroreductase or enzymatic activity in each trypanosome, leading to differences in the sensitivity of the tested compounds.

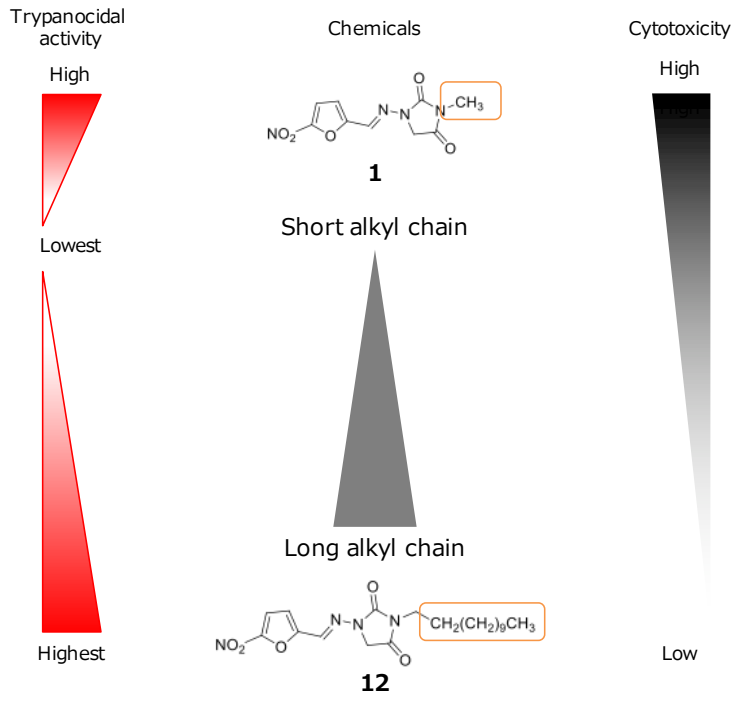

(a)

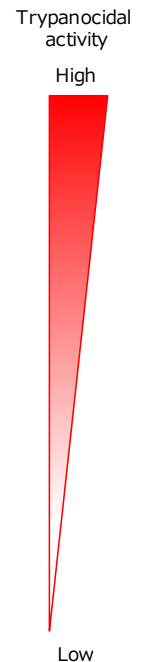

Low

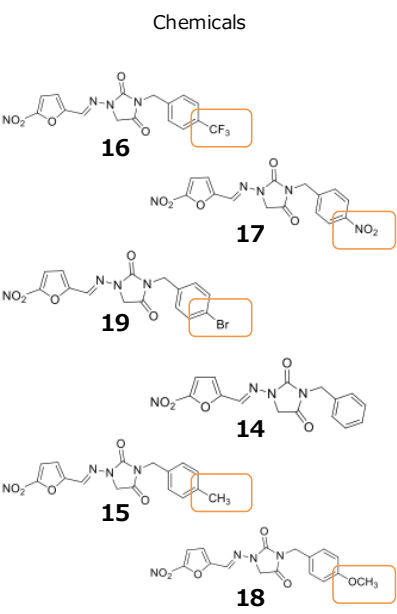

(b)

Figure 2. Summary of structure-activity relationship. The summary of structure-activity relationship between trypanocidal activity and alkyl chain length (a) or electronegativity (b).

Nitrofurantoin (Macrobid ${ }^{\circledR}$ ) is an antibiotic that is orally used to treat bladder infections. Nitrofurantoin shows extremely low lipophilicity ( $\log P-0.22)$, which may explain its poor trypanocidal activity, as it cannot efficiently permeate parasitic biomembranes. In contrast, analogs 1 and $\mathbf{2}$ have low cLogP values of -0.04 and 0.36 , respectively [11], which are relatively higher than those of nitrofurantoin, suggesting their moderately lipophilic nature. They were found to possess moderate $(0.19-0.73 \mu \mathrm{M})$ activity against the $T . b$. rhodesiense Chirundu and T. congolense IL3000 strains. HAT and AT are endemic diseases, mainly occurring in rural areas of developing countries, and persist because of the lack of healthcare and veterinary medicine infrastructure. Therefore, oral drugs are highly convenient for treating these diseases. Although they showed strong trypanocidal activities in vitro, no treatment efficacy was observed with nitrofurantoin analogs 9, 11, and $\mathbf{1 2}$ against $T$. congolense infection in vivo, after both oral and intraperitoneal administration. Oral treatment with nitrofurantoin, however, demonstrated partial efficacy. nitrofurantoin possessed weak trypanocidal activity in vitro, but dissolved in water with a lower clogP than that of the tested analogs, which were more lipophilic and thus had higher clogP values. This result supports that high-hydrosolubility nitrofurantoin analogs should be developed and evaluated for their in vivo trypanocidal activity, in further studies. Analogs $\mathbf{1}$ and $\mathbf{2}$ showing moderate in vitro trypanocidal activity and higher solubility (lower cLogP) than the current selectees may be viable starting points for developing oral treatments for HAT and AT in endemic areas [30]. 


\section{Materials and Methods}

\subsection{Chemicals}

The nitrofurantoin analogs (Table 1) were synthesized in moderate yields (50-65\%) in a single-step $N$-alkylation process through nucleophilic substitution $\left(\mathrm{S}_{\mathrm{N}} 2\right)$ [11]. The series of analogs was divided into two sub-series based on the nature of the substituent at the N-3 position. Thus, sub-series 1 comprised N-alkyl analogs 1-12, whereas sub-series 2 comprised benzyl-substituted analogs 13-19. The latter sub-series featured analogs 15 and 18, which bore the electron-donating groups $\mathrm{CH}_{3}$ and $\mathrm{OCH}_{3}$, respectively, whereas analogs 16, 17, and 19 possessed the electron-withdrawing groups $\mathrm{CF}_{3}, \mathrm{NO}_{2}$, and $\mathrm{Br}$, respectively. Analog 14 bore a neutral group $\mathrm{H}$, and analog 13 possessed an ethyl bridge between the nitrofurantoin scaffold and the benzyl group.

The analogs possessed lipophilic properties, with lipophilicity coefficients (clogP) in the targeted range of 1-5 [31,32]. They showed moderate to no toxicity in human embryonic kidney (HEK-293) and Chinese hamster ovary cells and exhibited anti-mycobacterial activity with $90 \%$ minimum inhibitory concentrations of $0.5-35 \mu \mathrm{M}$. The most potent antimycobacterial nitrofurantoin derivative was analog 8 , which was 30-fold more potent than nitrofurantoin [11].

These analogs were dissolved at $10 \mathrm{mg} / \mathrm{mL}$ in dimethyl sulfoxide and stored at -30 ${ }^{\circ} \mathrm{C}$ until use.

\subsection{In Vitro Cultivation of Trypanosomes and Madin-Darby Bovine Kidney Cells}

The bloodstream forms of T. b. brucei GUTat3.1, T. b. rhodesiense IL1501, T. b. rhodesiense Chirundu, T. b. gambiense IL1922, and T. evansi Tansui strains were propagated in culture at $37^{\circ} \mathrm{C}$, whereas the T. congolense IL3000 strain was propagated at $33^{\circ} \mathrm{C}$ in Hirumi's modified Iscove's medium-9, supplemented with $20 \%$ heat-inactivated fetal bovine serum [33]. The bloodstream form cultures were maintained by replacing the entire culture supernatant with fresh medium, every other day.

\subsection{Evaluation of Trypanocidal Activity and Cytotoxicity of Nitrofurantoin Analogs In Vitro}

The trypanocidal activity and cytotoxicity of nitrofurantoin analogs were evaluated according to previous reports [34,35], with some modifications. In brief, bloodstream forms adjusted at $2.5 \times 10^{3}$ cells $/ \mathrm{mL}(T . b$. brucei GUTat3.1, T. $b$. gambiense IL1922, and T. $b$. rhodesiense IL1501), $1 \times 10^{4}$ cells / $\mathrm{mL}$ (T. evansi Tansui and T. $b$. rhodesiense Chirundu), and 1 $\times 10^{5}$ cells $/ \mathrm{mL}$ (T. congolense IL3000), were cultivated in Nunc ${ }^{\circledR}$ MicroWell 96-well optical bottom plates (Thermo Fisher Scientific, Waltham, MA, USA) and exposed to various analogs at seven different concentrations for 3 days, in an incubator at $37^{\circ} \mathrm{C}\left(33^{\circ} \mathrm{C}\right.$ for $\mathrm{T}$. congolense IL3000). After 3 days of incubation, the condition of the bloodstream forms was observed with phase-contrast microscopy. Twenty-five microliters of the Cell-TiterGlo ${ }^{\circledR}$ (Promega, Madison, WI, USA) reagent was added into each well, and bioluminescence was measured using a GloMax ${ }^{\circledR}$-Multi+Detection System plate reader (Promega).

Additionally, Madin-Darby bovine kidney cells were cultivated (density, $1 \times 10^{4}$ cells $/ \mathrm{mL}$ ) in a 96-well cell culture plate (Thermo Fisher Scientific) with the analogs, at seven different concentrations for 3 days at $37^{\circ} \mathrm{C}$. Next, $10 \mu \mathrm{l}$ of the Cell Counting Kit8 solution (Dojindo, Kumamoto, Japan) was added into each well before and after $4 \mathrm{~h}$ of incubation. Absorbance was measured at $450 \mathrm{~nm}$ using a GloMax ${ }^{\circledR}$-Multi+Detection System plate reader.

The half maximum inhibitory concentration $\left(\mathrm{IC}_{50}\right)$ of each analog in trypanosomes and the Madin-Darby bovine kidney cells was calculated using the GraphPad Prism version 8 software (GraphPad, Inc., San Diego, CA, USA).

\subsection{In Vivo Evaluation of the Treatment Efficacy of Selected Nitrofurantoin Analogs}

Healthy female 8-week-old BALB/c mice (CLEA Japan, Inc., Tokyo, Japan) were used in this study. All animals had ad libitum access to normal chow and water. 
The virulent T. congolense IL3000 strain was propagated in a mouse and used for infection. The parasites were passaged once in a mouse before the experiment. The experimental mice were intraperitoneally infected with $100 \mu \mathrm{L}$ of $T$. congolense in phosphate-buffered saline, containing $10 \%$ glucose at $1 \times 10^{3}$ cells $/$ mouse. First, the mice were randomly divided into six groups of three mice, each as follows. Group I (no treatment), mice were not infected and were only treated with solvent (10\% dimethyl sulfoxide-phosphate-buffered saline). Group II received $3.5 \mathrm{mg} / \mathrm{kg}$ of diminazene aceturate treatment. Groups III (9), IV (11), V (12), and VI were treated with nitrofurantoin and the mice were infected and intraperitoneally treated with $0.1 \mathrm{mg} / \mathrm{kg}$ of the compound.

In the second experiment, the mice were randomly divided into six groups of three mice, each as follows-group I received no treatment; group II received $3.5 \mathrm{mg} / \mathrm{kg}$ of diminazene aceturate treatment; and groups III (9), IV (11), V (12), and VI received nitrofurantoin - the mice were infected and orally treated with $10 \mathrm{mg} / \mathrm{kg}$ of the compound.

Treatment was initiated at 2 days post-infection (dpi) and continued for seven consecutive days. The treatments were freshly prepared each day. Parasitemia was observed using a cell counting chamber until $14 \mathrm{dpi}$.

\section{Conclusions}

In conclusion, our results indicate that nitrofurantoin may be suitable as a lead compound for developing novel trypanocidal drugs, provided that compounds with good oral bioavailability and in vivo activity can be designed, particularly against animal African trypanosomosis caused by T. congolense and some confined endemic acute HAT infections caused by the T. $b$. rhodesiense Chirundu strain. Our preliminary in vivo experiments also showed that NF and its analogs with high water solubility should be evaluated to determine their treatment efficacy in mouse models, in further studies.

Author Contributions: Conceptualization, K.S. and D.D.N.; Investigation, K.S., L.M. and A.S.; Bio resources, B.N. and D.D.N.; Writing draft preparation, K.S., L.M. and D.D.N.; Review and editing, K.S., L.M., A.S., B.N., D.D.N., and N.I.; Funding, K.S. All authors have read and agreed to the published version of the manuscript.

Funding: The study was supported by the Japan Society for the Promotion of Science (JSPS), KAKENHI Grant Number 16K18793 [Grants-in-Aid for Young Scientists (B)] and Ohyama Health Foundation, Inc. The funders had no role in study design, data collection and interpretation, or the decision to submit the work for publication.

Institutional Review Board Statement: The experiment was approved by the animal ethics committee of Obihiro University of Agriculture and Veterinary Medicine (Approval No. 20-9).

Informed Consent Statement: Not applicable.

Data Availability Statement: Not applicable.

Acknowledgments: The authors would like to thank the Japan Society for the Promotion of Science (JSPS) and Ohyama Health Foundation, Inc. for providing financial assitance.

Conflicts of Interest: The authors declare no conflict of interest. The funders had no role in the design of the study; in the collection, analyses, or interpretation of data; in the writing of the manuscript, or in the decision to publish the results.

Sample Availability: Samples of the compounds are available from D.D.N.

\section{References}

1. Büscher, P.; Cecchi, G.; Jamonneau, V.; Priotto, G. Human African trypanosomiasis. Lancet 2017, 390, 2397-2409. [CrossRef]

2. Mwiinde, A.M.; Simuunza, M.; Namangala, B.; Chama-Chiliba, C.M.; Machila, N.; Anderson, N.; Shaw, A.; Welburn, S.C. Estimating the economic and social consequences for patients diagnosed with human African trypanosomiasis in Muchinga, Lusaka and Eastern Provinces of Zambia (2004-2014). Infect. Dis. Poverty 2017, 6, 150. [CrossRef] [PubMed]

3. Giordani, F.; Morrison, L.J.; Rowan, T.G.; De Koning, H.P.; Barrett, M.P. The animal trypanosomiases and their chemotherapy: A review. Parasitology 2016, 143, 1862-1889. [CrossRef] [PubMed] 
4. Morrison, L.J.; Vezza, L.; Rowan, T.; Hope, J.C. Animal African trypanosomiasis: Time to increase focus on clinically relevant parasite and host species. Trends Parasitol. 2016, 32, 599-607. [CrossRef]

5. Desquesnes, M.; Holzmuller, P.; Lai, D.H.; Dargantes, A.; Lun, Z.R.; Jittaplapong, S. Trypanosoma evansi and surra: A review and perspectives on origin, history, distribution, taxonomy, morphology, hosts, and pathogenic effects. BioMed Res. Int. 2013, 2013, 194176. [CrossRef]

6. Fairlamb, A.H. Chemotherapy of human African trypanosomiasis: Current and future prospects. Trends Parasitol. 2003, 19, 488-494. [CrossRef]

7. Wamwiri, F.N.; Changasi, R.E. Tsetse flies (Glossina) as vectors of human African trypanosomiasis: A review. BioMed Res. Int. 2016, 2016, 6201350. [CrossRef]

8. World Health Organization. WHO Interim Guidelines for the Treatment of Gambiense Human African Trypanosomiasis; World Health Organization: Geneva, Switzerland, 2019.

9. Mesu, V.K.B.K.; Kalonji, W.M.; Bardonneau, C.; Mordt, O.V.; Blesson, S.; Simon, F.; Delhomme, S.; Bernhard, S.; Kuziena, W.; Lubaki, J.-P.F. Oral fexinidazole for late-stage African Trypanosoma brucei gambiense trypanosomiasis: A pivotal multicentre, randomised, non-inferiority trial. Lancet 2018, 391, 144-154. [CrossRef]

10. Wang, Y.; Gray, J.P.; Mishin, V.; Heck, D.E.; Laskin, D.L.; Laskin, J.D. Role of cytochrome P450 reductase in nitrofurantoin-induced redox cycling and cytotoxicity. Free Radic. Biol. Med. 2008, 44, 1169-1179. [CrossRef]

11. Zuma, N.H.; Smit, F.J.; Seldon, R.; Aucamp, J.; Jordaan, A.; Warner, D.F.; David, D.D. Single-step synthesis and in vitro antimycobacterial activity of novel nitrofurantoin analogues. Bioorg. Chem. 2020, 96, 103587. [CrossRef] [PubMed]

12. Hall, B.S.; Wu, X.; Hu, L.; Wilkinson, S.R. Exploiting the drug-activating properties of a novel trypanosomal nitroreductase. Antimicrob. Agents Chemother. 2010, 54, 1193-1199. [CrossRef] [PubMed]

13. Roldán, M.D.; Pérez-Reinado, E.; Castillo, F.; Moreno-Vivián, C. Reduction of polynitroaromatic compounds: The bacterial nitroreductases. FEMS Microbiol. Rev. 2008, 32, 474-500. [CrossRef]

14. Kaiser, M.; Mäser, P.; Tadoori, L.P.; Ioset, J.-R.; Brun, R. Antiprotozoal activity profiling of approved drugs: A starting point toward drug repositioning. PLoS ONE 2015, 10, e0135556. [CrossRef]

15. Checchi, F.; Piola, P.; Ayikoru, H.; Thomas, F.; Legros, D.; Priotto, G. Nifurtimox plus eflornithine for late-stage sleeping sickness in Uganda: A case series. PLoS Negl. Trop. Dis. 2007, 1, e64. [CrossRef]

16. Priotto, G.; Kasparian, S.; Ngouama, D.; Ghorashian, S.; Arnold, U.; Ghabri, S.; Karunakara, U. Nifurtimox-eflornithine combination therapy for second-stage Trypanosoma brucei gambiense sleeping sickness: A randomized clinical trial in Congo. Clin. Infect. Dis. 2007, 45, 1435-1442. [CrossRef] [PubMed]

17. Steverding, D. The development of drugs for treatment of sleeping sickness: A historical review. Parasit. Vectors 2010, 3, 15. [CrossRef]

18. Wermuth, C.G. The Practice of Medicinal Chemistry; Academic Press: Cambridge, MA, USA, 2011.

19. Jorge, S.D.; Palace-Berl, F.; Pasqualoto, K.F.M.; Ishii, M.; Ferreira, A.K.; Berra, C.M.; Bosch, R.V.; Maria, D.A.; Tavares, L.C. Ligand-based design, synthesis, and experimental evaluation of novel benzofuroxan derivatives as anti-Trypanosoma cruzi agents. Eur. J. Med. Chem. 2013, 64, 200-214. [CrossRef] [PubMed]

20. Palace-Berl, F.; Pasqualoto, K.F.M.; Jorge, S.D.; Zingales, B.; Zorzi, R.R.; Silva, M.N.; Ferreira, A.K.; de Azevedo, R.A.; Teixeira, S.F.; Tavares, L.C. Designing and exploring active $\mathrm{N}^{\prime}$-[(5-nitrofuran-2-yl) methylene] substituted hydrazides against three Trypanosoma cruzi strains more prevalent in Chagas disease patients. Eur. J. Med. Chem. 2015, 96, 330-339. [CrossRef]

21. O'Shea, I.P.; Shahed, M.; Aguilera-Venegas, B.; Wilkinson, S.R. Evaluating 5-nitrothiazoles as trypanocidal agents. Antimicrob. Agents Chemother. 2016, 60, 1137-1140. [CrossRef]

22. Palace-Berl, F.; Pasqualoto, K.F.M.; Zingales, B.; Moraes, C.B.; Bury, M.; Franco, C.H.; da Silva Neto, A.L.; Murayama, J.S.; Nunes, S.L.; Silva, M.N. Investigating the structure-activity relationships of $\mathrm{N}^{\prime}$-[(5-nitrofuran-2-yl) methylene] substituted hydrazides against Trypanosoma cruzi to design novel active compounds. Eur. J. Med. Chem. 2018, 144, 29-40. [CrossRef]

23. Salas, C.O.; Faúndez, M.; Morello, A.; Diego Maya, J.; Tapia, R.A. Natural and synthetic naphthoquinones active against Trypanosoma cruzi: An initial step towards new drugs for Chagas disease. Cur. Med. Chem. 2011, 18, 144-161. [CrossRef] [PubMed]

24. Cuevas-Hernández, R.I.; Correa-Basurto, J.; Flores-Sandoval, C.A.; Padilla-Martínez, I.I.; Nogueda-Torres, B.; de Lourdes VillaTanaca, M.; Tamay-Cach, F.; Nolasco-Fidencio, J.J.; Trujillo-Ferrara, J.G. Fluorine-containing benzothiazole as a novel trypanocidal agent: Design, in silico study, synthesis and activity evaluation. Med. Chem. Res. 2016, 25, 211-224. [CrossRef]

25. Vera, B.; Vázquez, K.; Mascayano, C.; Tapia, R.A.; Espinosa, V.; Soto-Delgado, J.; Salas, C.O.; Paulino, M. Structural analysis and molecular docking of trypanocidal aryloxy-quinones in trypanothione and glutathione reductases: A comparison with biochemical data. J. Biomol. Struct. Dyn. 2017, 35, 1785-1803. [CrossRef] [PubMed]

26. Katsuno, K.; Burrows, J.N.; Duncan, K.; Van Huijsduijnen, R.H.; Kaneko, T.; Kita, K.; Mowbray, C.E.; Schmatz, D.; Warner, P.; Slingsby, B. Hit and lead criteria in drug discovery for infectious diseases of the developing world. Nat. Rev. Drug Discov. 2015, 14, 751-758. [CrossRef] [PubMed]

27. Finiuk, N.; Hreniuh, V.; Ostapiuk, Y.V.; Matiychuk, V.; Frolov, D.; Obushak, M.; Stoika, R.; Babsky, A. Antineoplastic activity of novel thiazole derivatives. Biopolymers Cell 2017, 33, 135-146. [CrossRef]

28. Liu, S.; Su, M.; Song, S.-J.; Jung, J.H. Marine-derived Penicillium species as producers of cytotoxic metabolites. Mar. Drugs 2017, 15, 329. [CrossRef] 
29. Hall, B.S.; Bot, C.; Wilkinson, S.R. Nifurtimox activation by trypanosomal type I nitroreductases generates cytotoxic nitrile metabolites. J. Biol. Chem. 2011, 286, 13088-13095. [CrossRef]

30. Tambosi, G.; Coelho, P.F.; Luciano, S.; Lenschow, I.C.S.; Zétola, M.; Stulzer, H.K.; Pezzini, B.R. Challenges to improve the biopharmaceutical properties of poorly water-soluble drugs and the application of the solid dispersion technology. Matéria (Rio Jan.) 2018, 23. [CrossRef]

31. Lipinski, C.A.; Lombardo, F.; Dominy, B.W.; Feeney, P.J. Experimental and computational approaches to estimate solubility and permeability in drug discovery and development settings. Adv. Drug Deliv. Rev. 1997, 23, 3-25. [CrossRef]

32. Lipinski, C.A. Chris Lipinski discusses life and chemistry after the Rule of Five. Drug Discov. Today 2003, 8, 12. [PubMed]

33. Hirumi, H.; Hirumi, K. In vitro cultivation of Trypanosoma congolense bloodstream forms in the absence of feeder cell layers. Parasitology 1991, 102, 225-236. [CrossRef] [PubMed]

34. Suganuma, K.; Allamanda, P.; Hakimi, H.; Zhou, M.; Angeles, J.M.; Kawazu, S.I.; Inoue, N. Establishment of ATP-based luciferase viability assay in 96-well plate for Trypanosoma congolense. J. Vet. Med. Sci. 2014, 76, 1437-1441. [CrossRef] [PubMed]

35. Suganuma, K.; Yamasaki, S.; Molefe, N.I.; Musinguzi, P.S.; Davaasuren, B.; Mossaad, E.; Narantsatsral, S.; Battur, B.; Battsetseg, B.; Inoue, $\mathrm{N}$. The establishment of in vitro culture and drug screening systems for a newly isolated strain of Trypanosoma equiperdum. Int. J. Parasitol. Drugs Drug Resist. 2017, 7, 200-205. [CrossRef] [PubMed] 